\title{
Effects of Cadmium and Selenium on The Hematological Parameters and Histopathology of Liver in Male Rats
}

\section{Talib Hussen Ali \& Ahmed Baker Ali Biology Department, Education College}

\section{Suha Mahmood Ahmed Physiology Department, Veterinary College,}

\section{Mosul University \\ الخلاصة}

الكادميوم و السيلينيوم من المعادن المتوفرة في البيئة على نطاق واسع و التي تحث على

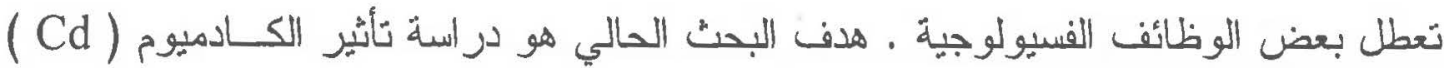

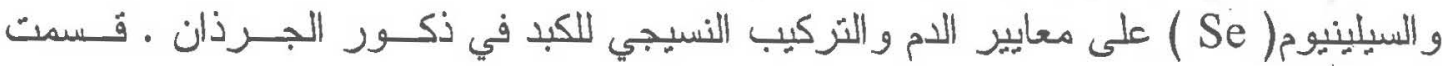

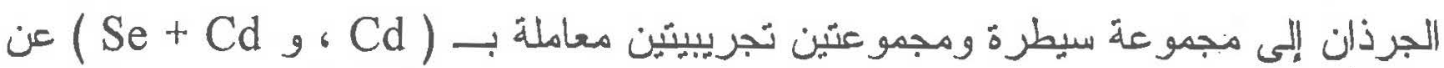

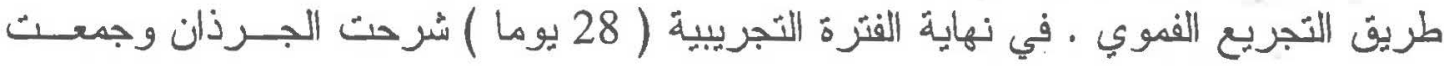
عينات الدم من القوس الوزيدي الظهري وتم دراسة نسبة حجم الخلاليا الدمويسـة المثر اصـــة

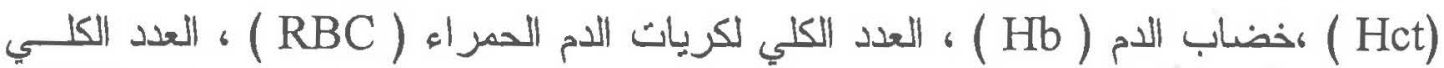

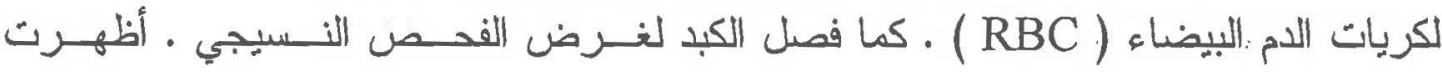
الارلسة أن هناك تغير افي قيم الـ Hct ، WBC ، RBC و في الجــرذان المعاملــة بالكادميوم ( Cd ) حيث انخفضت نسبتها انخفاضا دعنويا ( 0.05 > P ) . كذلك أظهرت

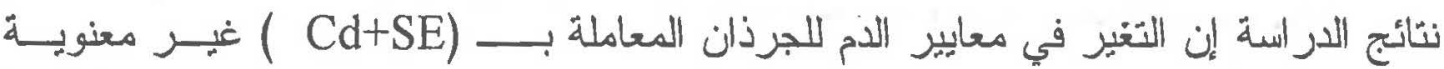

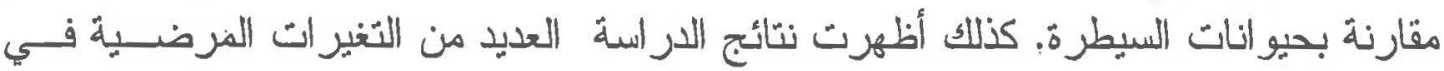

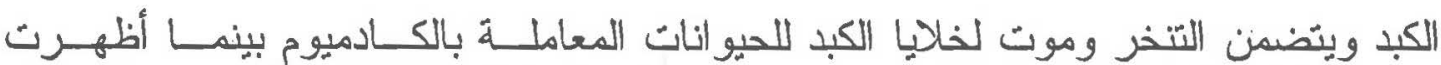

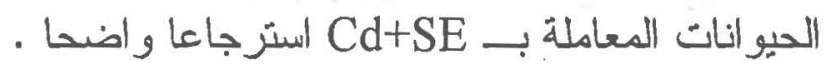

\section{Abstract}

Cadmium and Selenium are ubiquitous metals in the environment that induces a broad range of physiological dysfunctions. The purpose of this study was to investigate the chronic effect of Cadmium (Cd) and Selenium (Se) on rats blood parameters and histopathology of the liver in

- Presented at the first conference on Biology, University of Mosul ,college of Education, 4-5 September 2007 
the male rats. Animals were divided at random into a control and treated groups ( $\mathrm{Cd}$ and $\mathrm{Se}+\mathrm{Cd})$, both groups were fed with the same standard food, but Cadmium chloride, and mixture of Cadmium chloride +Selenium chloride were added to the drinking water of the experimental groups. At the end of the experiments periods ( 28 days ) the animals were sacrificed, blood samples were drawn via the dorsal vena cava, Hematocrit ( Hct \%), hemoglobin ( $\mathrm{Hb}$ ), number of erythrocytes count and of erythrocytes count were determined. Liver was dissected out for histological examination. There were different alteration in the blood parameters among different treated animals $(\mathrm{Cd}$ and $\mathrm{Se}+\mathrm{Cd})$ and control groups. They differences were statistically significant $(\mathrm{P} \leq 0.05)$ with $\mathrm{Cd}$ treatment. Also results showed that the positive or negative alteration of blood parameters was not significant for $\mathrm{Se}+\mathrm{Cd}$ mixture treated rats group.

A number of morphological change were observed in the liver, including a nuclear damage, necrosis and cell death at cadmium treatment and pronounced recovery after co-selenium supplementation indicted a considerable antagonistic effects .

It can be concluded that the $\mathrm{Cd}$ exposure impair certain hemorheological mechanism and increase tissue damage in liver, although Selenium showed beneficial effects to some extend. In summary, this study provides data on toxic effect in rats after dietary sub lethal supplementation to heavy metals.

\section{Introduction}

In recent years, increasing attention has been drawn to the effects of heavy metals present ubiquitously in the environment, on human and animal health .Heavy metals intoxication especially by lead, cadmium, arsenic and mercury constitutes treat to animal and human health [1]. The most obvious toxic effect of pollutants appears in the hematopoiesis process. It has been proposed that heavy metals acknowledge shortened life span of erythrocytes and inhibit of hemoglobin synthesis [2]. Cadmium is one of the most toxic substances in the environment with wide range of organ toxicity, along elimination half - life accumulates in blood and stored primarily in the kidney and liver and excreted through glomerular filtration in the kidney and may have toxic effect on several organs e.g hematopoietic system, the liver and kidney [3], [4] and [5] . Metal toxicicities might be associated with oxidative tissue damage and has been shown to stimulate the production of intracellular reaction oxygen species (ROS) [6]. Elucidation of $\mathrm{Cd}$ effect is important for mechanistic interpretation of metal toxic effects. Xenobiotic is an influential factors, which may have direct or indirect effect by generation 
bioactive molecules intracellularly (free radicals) causing functional and structural alteration at tissue levels [7].

This work is to report the synergistic or antagonistic interaction between pollutants in also relevant in the final toxic effects

\section{Materials and Methods}

Experiments were performed on adult male albino rats weighing $230-250 \mathrm{~g}$, animals were housed in laboratory and maintained at room temperatures $\left(25^{\circ} \mathrm{c}\right)$ and light/day cycle. $\mathrm{CdCl}_{2}$ was freshly dissolved in deionized water and the desired concentrations diluted from the stock solution $(7 \mathrm{mg} / \mathrm{L}$.). Before supplementation, male rats divided into a control and two experimental groups (groups of rats $n=7$ ), all were fed normal chow diet, but $\mathrm{Cdcl}_{2}$ and $\mathrm{Cdcl}_{2}-\mathrm{Secl}_{2}$ mixture were orally cavaged in the experimental groups. The first group was served as vehicle (untreated control), the second group were supplemented $7 \mathrm{mg}$ $\mathrm{Cdcl}_{2} / \mathrm{kg} /$ body weight while the third group treated with mixture of $7 \mathrm{mg} \mathrm{CdCl} l_{2}$ and $8 \mathrm{mg} \mathrm{SeCl} / 2 / \mathrm{kg} /$ body weight.

At the end of the experiments (28 days) animals killed by anesthetic overdose using ether. Blood was drawn via the dorsal vena cava and placed into heparinized tubes in the spiramix and then the blood was analyzed using automatic hematological analyzer ( Coulter ACT differential analyzer, Documentation, Bakman Coulter, Inc. Industrial Estate , Germany ) .The hematocrit, red blood cells count total and differential and percentage white blood cells count ( lymphocytes, monocytes, granulocytes, platelets, mean cell volume ,mean corpuscular hemoglobin and mean corpuscular hemoglobin concentration were counted .

\section{Light microscopic preparation}

For light microscopic preparation, liver was dissected out and small portion of the liver fixed in Bouin's solution for $16 \mathrm{~h}$ and subsequently dehydrated in ethanol series, cleared with xylene, infiltrated and embedded in paraffin wax. Thin section $(5 \mu)$ were cut and stained with hematoxylin - eosin for histological examination.

For organs somatic indices (liver, kidney and spleen) were dissected out weighted and calculated as a percentage of total body weight in order to provide information on the liver, kidney and spleen conditions using Diniz, et al, ${ }^{[8]}$ formulae with modification :

Somatic indices $(\mathrm{SI})=($ total organ weight $/$ initial body weight $) X 100$

\section{Statistical analysis}

The data were analyzed using one way - ANOVA with a Duncan post test (SPSS, V.11.5 for windows) for significant differences. 


\section{Results}

Table ( 1 ) shows the various blood parameters including the hematocrit, red blood cells count total and differential and percentage white blood cells count (lymphocytes, monocytes, granulocytes ), platelets, mean cell volume, mean corpuscular hemoglobin and mean corpuscular hemoglobin concentration the three groups of rats. There were different alteration in the blood parameters among different treated animals $(\mathrm{Cd}$ and $\mathrm{Se}+\mathrm{Cd})$ and control groups .They differences were statistically significant $(\mathrm{P} \leq 0.05)$ with $\mathrm{Cd}$ treatment. Also results showed that the positive or negative alteration of blood parameters was not significant for $\mathrm{Se}+\mathrm{Cd}$ mixture treated rat group.

A number of morphological change were observed in the liver, including a nuclear damage, necrosis and cell death at cadmium treatment and pronounced recovery after selenium supplementation with considerable antagonistic effects of Selenium + cadmium treatment .

Table. 1. Hematological analyses of rat blood after different treatments

\begin{tabular}{|c|c|c|c|}
\hline $\begin{array}{c}\text { Hematological } \\
\text { parameters }\end{array}$ & Non - treated & $\mathrm{Cd}$ & $\mathrm{Cd}+\mathrm{Se}$ \\
\hline $\mathrm{RBC}_{\mathrm{S}} \times 10^{6} / \mathrm{mm}^{3}$ & $7.5320 \pm 0.10426$ & $5.31 \pm 0.764^{*}$ & $6.658 \pm 1.25$ \\
\hline$W_{B} \times 10^{3} / \mathrm{mm}^{3}$ & $13.08 \pm 1.0305$ & $7.08 \pm 0.78^{\star \star}$ & $18.18 \pm 3.123^{*}$ \\
\hline $\mathrm{Hb} \mathrm{g} / \mathrm{dl}$ & $13.92 \pm 1.064$ & $10.14 \pm 1.453^{\prime \prime}$ & $15.34 \pm 0.336^{\prime \prime}$ \\
\hline Platel. $\times 10^{3} / \mathrm{mm}^{3}$ & $856.6 \pm 8.8487$ & $365.8 \pm 30.08^{* n}$ & $867.6 \pm 55.716$ \\
\hline HCT $\%$ & $41.62 \pm 0.249$ & $27.4 \pm 2.966$ & $37.26 \pm 6.602$ \\
\hline Lym $\times 10^{3} / \mathrm{mm}^{3}$ & $8.2 \pm 0.55768$ & $5.32 \pm 0.973^{*}$ & $12 \pm 2.745^{*}$ \\
\hline Mon $\times 10^{3} / \mathrm{mm}^{3}$ & $1.22 \pm 0.23875$ & $1.16 \pm 0.054$ & $1.66 \pm 0.4505$ \\
\hline Gran $/ \mathrm{mm}^{3}$ & $4.16 \pm 0.36469$ & $0.84 \pm 0.364^{* *}$ & $4.82 \pm 0.396$ \\
\hline \% Lymphocyte & $62.12 \pm 3.212$ & $71.78 \pm 6.448$ & $63.56 \pm 3.656$ \\
\hline$\%$ Monocyete & $8.68 \pm 1.4481$ & $16.14 \pm 1.226$ & $8.88 \pm 2.193$ \\
\hline$\%$ Granulocyte & $28.04 \pm 4.01222$ & $14.36 \pm 3.454$ & $13.66 \pm 2.682$ \\
\hline $\operatorname{MCV}\left(\mathrm{nm}^{3}\right)$ & $54.9 \pm 0.35355$ & $52.94 \pm 1.457$ & $54.48 \pm 1.896$ \\
\hline $\mathrm{MCH}(\mathrm{Pg})$ & $19.48 \pm 0.19235$ & $18.4 \pm 0.57$ & $18.86 \pm 0.296$ \\
\hline $\operatorname{MCHC}(g / d l)$ & $34.44 \pm 0.2881$ & $34.6 \pm 0.114$ & $34.7 \pm 0.809$ \\
\hline
\end{tabular}

"Significant, very significant

Data are expressed as mean \pm S.E.M $(n=7) . \mathrm{RBC}_{\mathrm{S}}$ ( red blood cells count ), $\mathrm{WBC}_{\mathrm{S}}$ ( total white blood cells count), Hematocrit, Lym ( lymphocyte count), Mon ( Monocyte count), MCV ( Mean 
corpuscles volume ) $\mathrm{MCH}$ ( Mean corpuscle hemoglobin ) MCHC (Mean corpuscle hemoglobin concentration ).

Light microscope observation revealed that treatment with Cadmium for 28 days $7 \mathrm{mg} / \mathrm{kg} /$ body weight induced a number of morphological changes in the liver including nuclear damage, a marked cytoplasmic vaculation, liver necrosis and eventually followed by regenerative cell and cell death (fig. $1 \mathrm{~b}$ ) The relative low levels of liver injury was observed in rats exposed to cadmium and selenium combination Fig ( 1c ) showed hepatocyte recovery indicated by almost normal cytoplasmic appearance and normal cell shape .

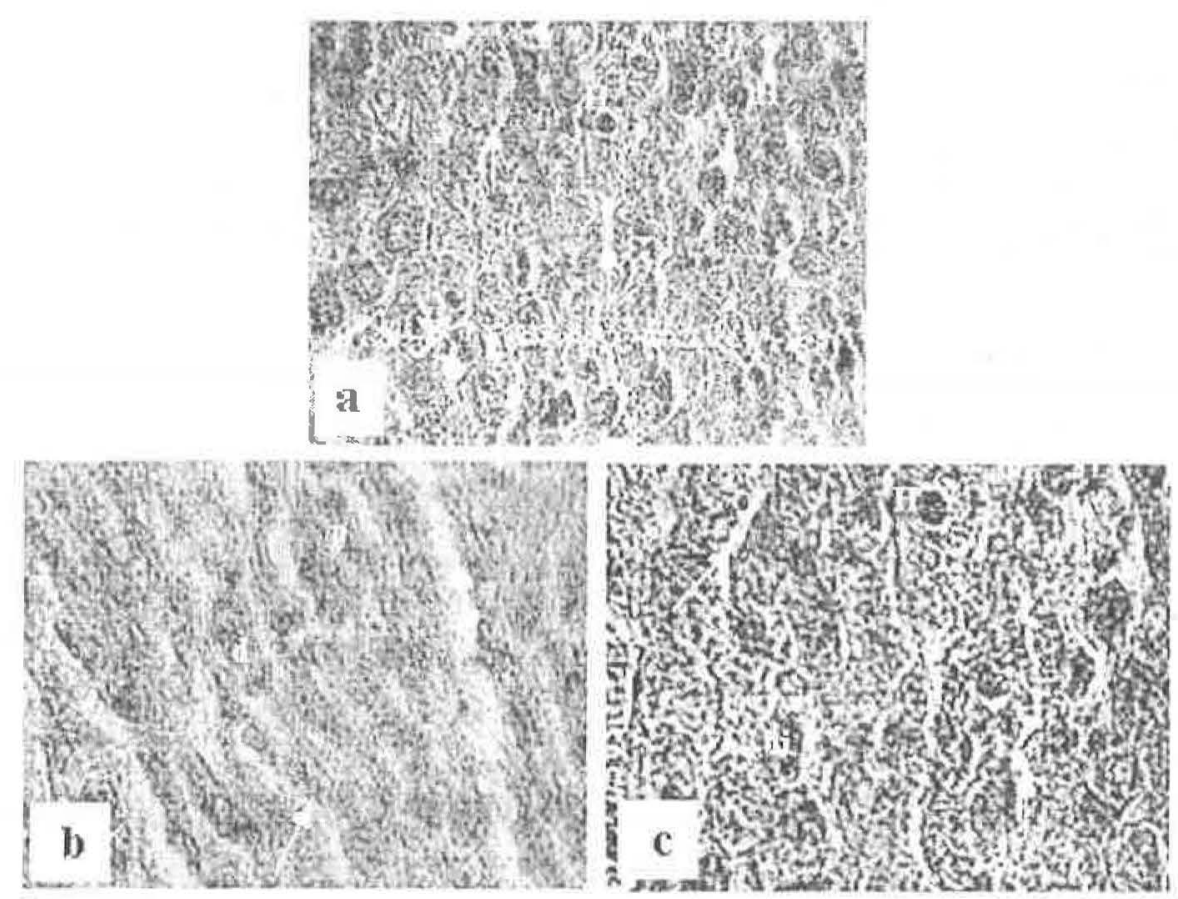

Fig (1). Transverse section of liver rat treated with $\mathrm{Cd}$ and $\mathrm{Cd}+\mathrm{Se}$.

(H-Hepatocyte, V-Vacuolization, $\mathrm{d}$-degeneration , arrows-- Sinusoid and $b$ - binucleated )

Fig. 2. Showed the Somatic index ( SI ) which indicate that the weight of the liver, kidney and spleen expressed as parentage of body weight, was lower in $\mathrm{Cd}$ treated animal group in both liver and kidney and slightly higher in the spleen. Statistical analysis $(p<0.05)$ showed there were no significance alteration in SI for all organs in the study in Se $+\mathrm{Cd}$ treated animal groups.

The weight of body organs expressed as percentage of body weight, was lower in $\mathrm{Cd}$ treated group in liver and kidney, while the weight of spleen elevated as compared with control and $\mathrm{Cd}+\mathrm{Se}$ treated animal groups ( Fig. 2.) 

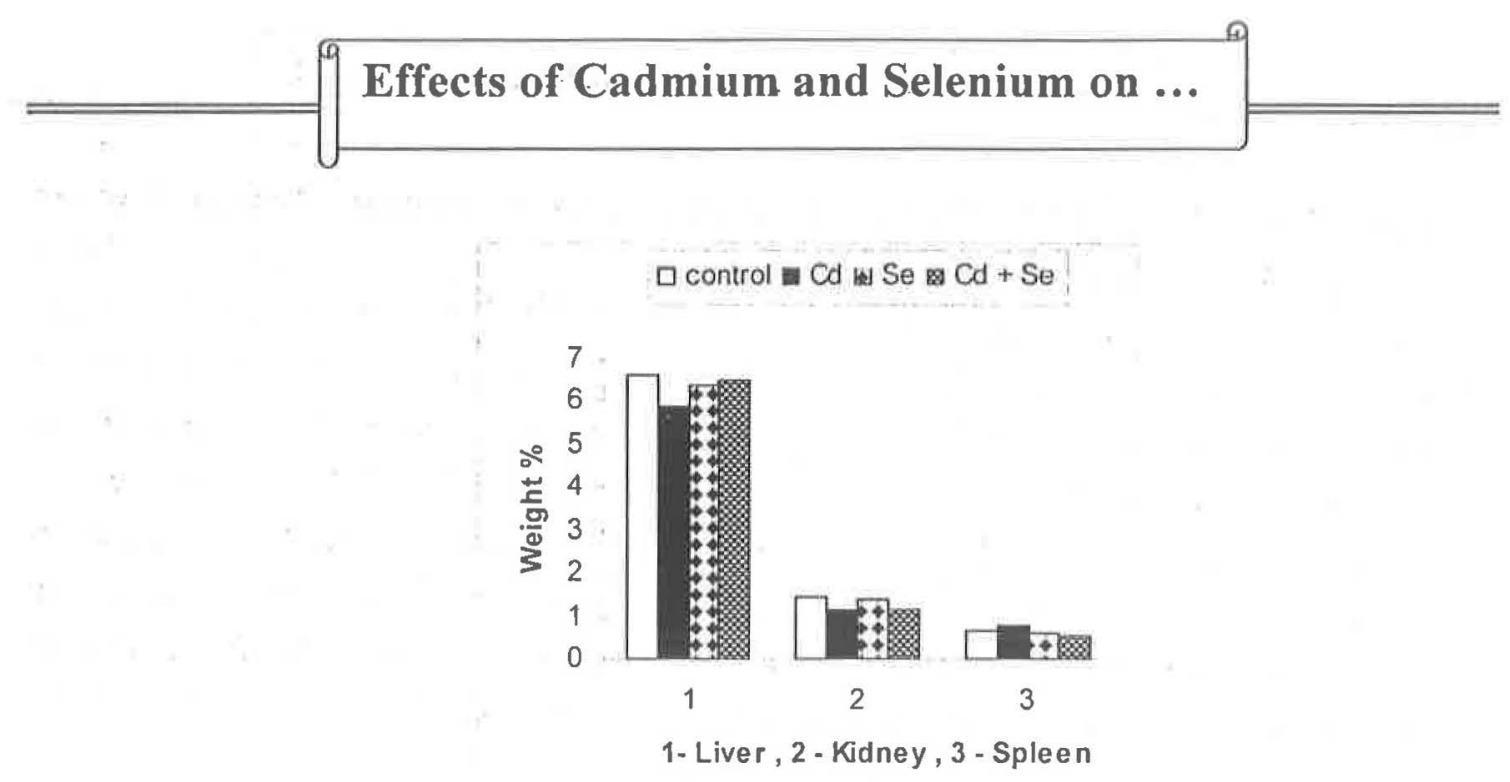

Fig. 2. Somatic index (SI) of control and treated rats

\section{Discussion}

The major challenge in experimental ecotoxicological studies is to cope with the relative paucity of literature on toxicity induced by dietary exposure. Environmental pollution may elicit both adaptive and adverse response in animals at different structural levels, i.e, cells, tissues and organs. These reactions depend on a variety of factors, such as the type of contaminant and its concentration, the rate of exposure and the susceptibility, of the organisms [9]. The present study investigated the effect of the sub lethal dose of $\mathrm{Cd}$ on the blood parameters and its subsequent effects on liver tissue of rats exposed to different treatments.

The results (table .1) showed that blood parameters as well as the liver tissue were markedly affected especially by $\mathrm{Cd}$ treatment .This work is to report the use of acute dietary exposure and to evaluate the synergistic or antagonistic interaction between pollutants also in relevant the final toxic effects of toxic metals $\mathrm{Cd}$ and $\mathrm{Se}$ in rats and to describe hemorheological and histophathological observation conducted at laboratory experiments.

The different miner alteration effect of $\mathrm{Cd}$ on the blood parameters and among other treatment ( $\mathrm{Se}+\mathrm{Cd})$ and control group in this study. This is due to $\mathrm{Cd}$ accumulation is a time - dependent process and $\mathrm{Cd}$ accumulation rates were considerably lower in haemocytes as compared to other tissues. Slow $\mathrm{Cd}$ accumulation in haemocyte, prevent them from reaching the threshold $\mathrm{Cd}$ burdens required to trigger apoptosis [10] Moreover, the significant decline of granulocyte percentage (granulocytes which comprise $30 \%$ of rat leukocytes population) in the present study this might be due to the ability of granulocyte to sequester the metals by migrating into connective tissue and intracellular spaces or transport metals to kidney for elimination. Nair and Robinson ${ }^{[1]}$ found that Oyster 
granulocytes which comprise $70-75 \%$ of Oyster haemocytes population can sequester metals by migrating into connective tissue and intracellular spaces or/and transport metals to kidney for elimination, thus effectively removing $\mathrm{Cd}$ fro circulation. Results of the present study also shows that there was no considerable effect of sub lethal dose of $\mathrm{Se}+\mathrm{Cd}$ treatments on the rat blood parameters as compared with the non-treated animal group. The synergistic or antagonistic interaction between pollutants is also relevant in the final toxic effects of metal $\mathrm{Cd}$ and $\mathrm{Se}$ in rats and to describe hemorheological and histophathological observation conducted at laboratory experiments these results are with comply with Fenoglio, et al, [9] speculation that the synergistic or antagonistic interaction between pollutants is also relevant in the final toxic effect . Some trace elements such as cadmium $(\mathrm{Cd})$ and lead $(\mathrm{Pb})$ have toxic effects on living organisms and are considered as contaminants. Other trace elements, such as selenium (Se) are not essential to plant growth but are required by animals and human beings [12]. The liver is the primary target organs of various toxicants, experimental studies in various species of rodent have documented the hepatotoxicity of oxidant substances, no animal species seems to be resistant although they have different susceptibility to toxicant [13] .

Fig( 1). In the present study, rats treated with Cadmium for up to 28 days develop progressive liver alteration characterized by cytoplasmic vacuolation, necrosis, regenerative and eventually followed by cell death. The liver damage have also reported in other mammalian and non mammalian species already studied [14]. Beside direct damage to proteins another underlying mechanism for toxicant induce cell injury may have influential factors which may have direct or indirect effect by generation bioactive molecules intracellularly ( e.g free radicals ) causing functional and structural alteration at tissue levels, due to: the ability of oxidant substances to cause oxidative stress in the liver [7], [13] and [15] . Cadmium is an extremely toxic environmental contaminant that causes the production of reactive oxygen species (ROS) such as hydroxyl radicals; superoxide anions, nitric oxide and hydrogen peroxide [6]. Increase production of ROS in the responses of the rat liver exposed to environmental pollution. In the present work, the relative low levels of liver injury was observed in rats exposed to Selenium - cadmium combination may be attributed to the antioxidant effect of Selenium which induces hepatocyte recovery, this is interrelated to detoxification involvement of enzymatic scavenger activity and Selenium antioxidant properties . These speculation is in comply with similar result interpretations on other mammalian and non mammalian species already studied [9] and [18]. Scalia et al, ${ }^{[17]}$ mentioned that the liver of albino rats susceptible to oxidative agents and found that melanin can act as 


\section{Effects of Cadmium and Selenium on ...}

reducing agent and replace antioxidant activity of superoxide dismutase (SOD).

The results presented indicates that supplemented selenium improves the great rate, decrease the cadmium uptake from gastrointestinal tract and alter the cadmium distribution in rats exposed to moderate amount of cadmium , similar results obtained but with Vitamin C supplementation [20], this may support the assumption that antioxidant plays beneficial role in reducing the toxicity and absorption of cadmium .Moreover, the influence of antidotes ( Se ) on cadmium uptake varied with the organs in this study, liver, kidney and spleen .

There is no adequate data available on the effect of cadmium and other related heavy metals on rats liver, kidney and spleen at organ level (weight index) to compare the present results with, although few studies refer to the negative effects of organic and inorganic oxidant on the reproductive organs such as testes weight and there was no effect on liver in particular [19].

Results of this study shows the Somatic index (SI) of liver, kidney and spleen were lower in $\mathrm{Cd}$ treated animal group in both liver and kidney and slightly higher in the spleen. Statistical analysis $(p<0.05)$ showed there was no significance alteration in SI for all organs in the study in $\mathrm{Se}$ and $\mathrm{Se}+\mathrm{Cd}$ treated animal groups. Mukherjiet al, ${ }^{[20]}$ pointed out that an alteration in fish hepatic indices caused by exposure to pollutants may cause liver dysfunction. 


\section{References}

[1]Hu , H.Prim .Care. 27: 983 - 996. (2000).

[2]Toplan, S; Ôzcelik, D; Gulyasar, T and Akyolcu, M. C.J .Trac. Med. Biolo. 18: 179 - 182 . (2004).

[3]Fiberg, L. Environ. Health perspect. 54: 1 - 41.( 1984)

[4]Jarup,L;Beglund, $M$ and Elinden,C.G.Scan.Work.Enivron. Health. 24: 1- 51.( 1998 ).

[5]Skerfving, S; Gerhardson, L ; Schütz, A and Strömberg, U . J. Trace Elem. Exp. Med. 11: 289 - 301. (1998)

[6]Stohs, S. T; Bagchi, D; Hassoun, E and Bagchi, M. J. Environ. Pathol. Toxicol. Oncol. 20 ( 2 ) : $77-88$. (2000).

[7]Williams, G. M and Iatropoulos, M. J. Toxicol. Pathol. 30:41 - 53. (2002).

[8]Diniz, M.s; Peres, I; Antoine, I.M; Falla, J and Pihan, J.c. Ecotoxicology and environmental safety. 62:427-435 . (2002).

[9]Fenoglio,C; Boncompagini , E; fasola, M; Gandini, C; comizzoli, S; Milanesi, E, and barni,S. Ecotoxicology and Environmental Safety .60: 259-268. (2005).

[10]Cherkasov, A.S; Grewal, S and Sokolova I.M.J.Them. Biolo.32:162170. (2007).

[11]Nair, P.s and Robinson, W. E. Aquat. Toxicol. 52: 133 - 142. (2001). [12]He, Z.l; Yang, $\mathrm{x}$ and Stoffella, P.J. J Trace Elements in Medicine and Biology. 9 (2-3): 125 -140. (2005).

[13]Meki, A, Esmail, E; Hssein, A and Hassanein, H .M.. Toxicon. 43: 93 - 100.(2004).

[14]Cohen, S.M and Ellwein, L. B. Science. 1007 - 1011.( 1990) .

[15]Shen, M. M; Shi, C.Y; Lee, H. P and Ong, C. N. Toxicol. Appl. Pharmacol. 127: 145 - 150. (1994).

[16]Coraso , C.; Scalia , M ; Blanco, A .N ; Aiello, I and Sachem, G . Cell .Res . 8: 279-2(1995).

[17]Scalia, M; Geremio, F; Corsaro, C; Satoro, C . Baratta, D and Sichel, G. Pigment Cell. Res. 3: 115 - 119. (1990).

[18]Grosicki, A. J. Trace element in Medicine and Biology. 18 : 183 187 . (2004).

[19]Latchoumycandane, C.; Chitra, K.C.; and Mathur, P.P. Reprod.Toxicol. 16 (2) : $161-172$.(2002)

[20]Mukherjee, D; Guha, D; Kuma, V and Chakrabary, S Aquat. Toxicol. 21 (1-2): $29-40.1991)$ 